УДК 1174

\title{
НАУЧНО-МЕТОДИЧЕСКИЕ АСПЕКТЫ ПРОБЛЕМЫ ФОРМИРОВАНИЯ ОСНОВ КУЛЬТУРЫ ЗДОРОВЬЯ У ДЕТЕЙ И ПОДРОСТКОВ
}

\author{
Макеева Александра Германовна \\ канд. пед. наук, ст. науч. сотрудник \\ ФГБНУ «Институт возрастной физиологии \\ Российской Академии Образования»
}

\begin{abstract}
Аннотация: В статье рассматриваются основные подходы к определению понятия «здоровье», а также основные модели организации здоровьесберегающей деятельности педагога (принципы, форматы, содержание). Анализируется опыт работы одной из наиболее эффективных программ формирования культуры питания - «Разговор о правильном питании».
\end{abstract}

Ключевые слова: Питание, здоровье, воспитание, здоровьесберегающая деятельность, методы воспитания.

Abstract: The article discusses the main approaches to the definition of the concept of "health", as well as the main models of the organization of health-saving activity of a teacher (principles, formats, content). The article analyzes the experience of one of the most effective programs for the formation of a nutrition culture - "Conversation about proper nutrition".

Key words: Nutrition, health, education, health-saving activity, methods of education.

Валеологическое направление, связанное с формированием у детей и подростков основ культуры здорового образа жизни - одно из наиболее популярных и актуальных в современной педагогике. Сегодня в практику различных образовательных учреждений внедряется большое число программ, направленных на формирование основ здорового образа жизни у детей и подростков. Но вот беда - далеко не всегда, несмотря на несомненную важность и значимость декларируемых целей и задач, программы эти 
оказываются эффективными. Причин тому может быть названо много, однако наиболее существенными среди них, на наш взгляд, являются следующие: узко прагматическое, упрощенное понимание здоровья как социокультурного феномена, лежащее в основе программы или педагогической методики, несоответствие содержания программы особенностям установок и представлений, связанных со здоровьем, присущим подростковой субкультуре, а также неадекватность предлагаемых форм и методов педагогического воздействия возрастным особенностям подростков.

Понятие о здоровье как определенном состоянии организма появилось в человеческой культуре очень давно - тогда же, когда стала зарождаться древняя медицина. На протяжении многих веков менялись критерии и эталонные характеристики здоровья, понимание его роли в жизни человека и общества, при этом содержание понятия здоровье всегда оставалось тесно связано с базовыми идеями актуальной культуры, являясь ее продуктом.

Так, сегодня для характеристики здоровья, по самым приблизительным подсчетам существует около 300 различных определений, в которых используются самые разные критерии. При этом сами определения можно разделить на три большие группы. Первая группа носит «нормоцентрический» характер и описывает здоровье как «совокупность среднестатистических норм восприятия, мышления, эмоционального реагирования и поведения, в сочетании с нормальными показателями соматического состояния индивида»[1].

Между тем, сущность здоровья не может быть сведена лишь к некоему набору среднестатистических физических и физиологических норм и параметров. Здоровье - сложный, многомерный феномен, отражающий различные аспекты человеческого бытия, его взаимосвязи и взаимодействие с окружающим миром. Сложная, комплексная сущность здоровья отражена во второй группе определений, описывающих здоровье не только в границах индивида и личности, но выходящих за эти границы, охватывающих социальные связи человека. Вторая группа определений носит «адаптационный» характер. Самое популярное среди них сегодня дано Всемирной организацией здравоохранения - «Состояния полного физического, душевного и социального благополучия».

Сегодня все чаще концепции здоровья включают в себя и сферу творческого, духовного развития личности. Подлинно здоровый человек в 
этом случае тот, кто не просто «благополучен», но стремится к совершенствованию, раскрытию и преумножению собственных способностей и возможностей, расширению связей с окружающим миром. Здоровье рассматривается в системе культурных, нравственных координат [2]. Именно такая - «антропоцентрическая модель» наполняет заботу о собственном здоровье глубоким смыслом, позволяет человеку рассматривать ее не как деятельность, «замкнутую на себя», а «размыкает» ее, направляя вовне, расширяя сферу возможностей и способностей человека. Антропоцентрическая модель меняет содержание мотивов здоровьесберегающей деятельности, ее прагматический характер (я забочусь о здоровье, чтобы ничего не болело, чтобы добиться успеха, благополучия и т.д.) постепенно замещается альтруистическим (заботясь о собственном здоровье я совершенствую себя и мир вокруг).

Антропоцентрическая модель здоровья в наибольшей степени соответствует парадигме глобальных философских концепций 20 века, гуманистическому мировоззрению, развивающемуся в культуре Нового времени. Она может стать основой формирования и культуры здоровья современного человека.

Одно из важнейших условий эффективности воспитательной работы, связанной с формированием основ культуры здоровья - ее социокультурная адекватность, которая выражается, в том числе, и в учете уже сложившихся в подростковой субкультуре представлений и нормативных оценок, связанных с здоровьем. Подростки не готовы и не смогут принять нормы и ценности (даже объективно полезные и важные), если они противоречат, идут вразрез с их актуальными представлениями и оценками.

Для того чтобы определить - как подростки воспринимают понятие «здоровье», есть ли какие-то особенности в отношении современных тинейджеров к проблеме здоровья и здорового образа жизни, мы провели опрос среди школьников 14-16 лет, а также среди их педагогов. Такое построение исследования не случайно. Педагоги сегодня - основные «реализаторы» важной воспитательной задачи - формировании культуры здоровья у подрастающего поколения. Успешность ее решения во-многом зависит от того - насколько совпадают ценностные ориентации и нормативы у участников воспитательного процесса - взрослых и подростков [3]. 


\section{ОБУЧЕНИЕ, РАЗВИТИЕ И ВОСПИТАНИЕ ЛИЧНОСТИ СЕГОДНЯ: ТЕНДЕНЦИИ, ПРОБЛЕМЫ, ПУТИ РЕШЕНИЯ}

Оказалось, что здоровье входит в круг социальных приоритетов и подростков, и взрослых. У школьников оно занимает 2 место (после фактора «семейное благополучие»), а у педагогов - на первом. Чаще всего наши респонденты характеризуют сущность здоровья как состояние физического и психического благополучия. Реже используются характеристики, связанные с описанием здоровья как условия социального благополучия. И наименее значимыми оказались характеристики здоровья как условия личностного роста и самореализации

Большинство подростков и взрослых высказали мнение о том, что здоровье человека «полностью зависит от него самого» или зависит «в большой степени».

При этом тревогу вызывает то, что в группе подростков весьма небольшое (с учетом его реальной важности) значение придается такому фактору как сохранения здоровья как отказ от употребления алкоголя и курения. Подростки не рассматривают наркотизацию как существенную угрозу здоровью.

Несмотря на то, что и подростки, и взрослые отнесли здоровье к числу приоритетных жизненных ценностей, их образ жизни сложно назвать здоровым. Так, только треть подростков и лишь 15\% взрослых регулярно занимаются спортом, лишь $25 \%$ школьников и $20 \%$ педагогов спят не менее 7 часов, $13 \%$ юношей и девушек и $15 \%$ взрослых соблюдают режим питания и т.д.

При обосновании причин - почему не соблюдаются те или иные правила здорового образа жизни, и подростки и взрослые чаще всего сетуют на «нехватку времени», «загруженность домашними делами», «нехватку материальных средств», и гораздо реже упоминают о личностных факторах дисциплинированности, организованности, наличии знаний о том, как заботиться о своем организме.

Получается, что в структуре социокультурных представлений современных подростков о здоровье существуют содержательные и оценочные компоненты, одни из которых могут служить в качестве опоры, нормативного подкрепления при формировании основ культуры здоровья, а другие позволяют определять содержательные задачи воспитательного процесса - что следует изменить или усилить в ценностно-нормативной сфере 
подростков, для того, чтобы забота о здоровье стала актуальной потребностью.

Одним из направлений, связанных с воспитанием культуры здоровья является формирование основ правильного питания. Состояние проблемы, связанной с питанием детей и подростков, вызывает обоснованную тревогу. В рационе современных школьников зачастую отсутствуют многие полезные продукты и блюда, не соблюдается режим питания, преобладает фаст-фуд и т.д.

Причины сложившейся ситуации многообразны - они носят экономический, социальный характер. Однако немаловажную роль здесь играют и культурные факторы, обусловленные несформированностью у детей и подростков полезных привычек и навыков, связанных с питанием. Как показали наши исследования, среди своих любимых продуктов и блюд называют овощи и фрукты лишь 35\% младших школьников, рыбные блюда$23 \%$, молоко и молочные продукты - $45 \%$. Лишь $35 \%$ школьников знают о том, каким должен быть правильный режим питания, 67\% соблюдают основные правила гигиены питания и т.д. Таким образом, формирование основ культуры питания у детей и подростков сегодня должно стать важной составляющей при решении задачи совершенствования организации школьного питания.

В настоящее время в мире реализуется более 300 национальных образовательных программ, направленных на обучение школьников основам правильного питания. Одной из таких программ является программа «Разговор о правильном питании» [4].

Программа состоит из трех структурных модулей, рассчитанных на детей 6-8 лет, 9-11 лет, подростков 12-14 лет, реализуется в различных образовательных учреждениях - школах, детских садах, интернатах, гимназиях и т.д.

Организация обучения правильному питанию соответствует следующим принципам:

- возрастная адекватность (вся информация и все формируемые навыки у школьника должны быть востребованы в его повседневной жизни).

- социокультурная адекватность. Формируемые навыки и привычки должны находить отражение в актуальной культуре общества, учитывать 
сложившиеся традиции и обычаи питания, специфику основных пищевых ресурсов.

- системность. Формирование полезных привычек - длительный и сложный процесс, охватывающий все стороны жизни ребенка. Воспитание культуры питания не может быть ограничено отдельными беседами или занятиями со школьниками. Важно, чтобы в повседневной жизни они также находили подтверждение важности и эффективности соблюдения правил рационального питания.

Организация воспитательного процесса должна учитывать особенности конкретной возрастной группы. Они определяют как содержание и задачи обучения, так и формы организации обучения в данном возрасте [5].

Несмотря на то, что основная цель деятельности, связанной с формированием полезных привычек и навыков в области правильного питания заключается в укреплении здоровья ребенка или подростка, эффективность работы в данном случае не может определяться по изменениям в состоянии здоровья школьников, изменениям уровня распространенности заболеваний ЖКТ и т. д (к сожалению, именно эти параметры довольно часто используют как практические работники, так и научные эксперты для демонстрации результатов деятельности). Здоровье - сложное, многоаспектное явление, зависящее от множества причин и факторов, имеющих различную природу - биологических, экономических, культурных, политических и т.д.

Целенаправленная, научно и методически обоснованная работа по формированию основ культуры питания безусловно оказывает влияние на ситуацию, связанную с состоянием здоровья школьников, однако не может определять ее целиком.

Исходя из этого, в качестве основного параметра эффективности работы по воспитанию основ культуры питания предлагается рассматривать изменения в социальных компетенциях, связанных с рациональным питанием (системе представлений, оценок, навыков).

Оценка эффективности выполняет целый ряд важных задачи:

a) диагностики - определение сферы и характера изменений, вызванных воспитательными воздействиями. 
b) коррекции - изменения в содержании и структуре реализуемой воспитательной модели (программы), связанной с формированием основ культуры питания с целью ее оптимизации

c) прогноза - планировании новых этапов реализации с учетом достигнутого.

Организация оценки должна базироваться на простых в использовании методиках, не требующих особой профессиональной подготовки, отсутствующей $\mathrm{y}$ основных участников воспитательной работы по формированию основ культуры питания. К ним могут быть отнесены опросы, экспертные оценки, анкетирование и т.д.

Оценка эффективности может быть внутренней и внешней. Внутренняя оценка осуществляется непосредственными участниками, реализующими программы формирования основ культуры питания в образовательном учреждении. Для внешней оценки привлекаются специалисты-эксперты, не принимающие непосредственного участия в реализации программ.

\section{Список литературы}

1. Абрамова Е.С. Источники информации подростков о здоровом образе жизни // Научно-методический электронный журнал «Концепт». 2015. - № 1 (январь). - С. 56-60

2. Ищенко А.В. Здоровье как ценность и педагогическая практика. Высшее образование в России. 2006; 12: 87-89.

3. Макеева А.Г. Научно-методические аспекты формирования основ культуры здоровья у детей и подростков. Вестник московского образования. 2019; 15: 182-92

4. Макеева А.Г. Возможности использования образовательных программ в формировании основ культуры здоровья. Биология в школе. 2014; 4: $20-28$.

5. Макеева А.Г. О формировании основ культуры здоровья у подростков. Биология в школе. 2008;1: 3-10. 